\title{
Efektivitas Model Pembelajaran Kooperatif Tipe Tutor Sebaya Dan Tipe Jigsaw Terhadap Hasil Belajar Matematika Siswa
}

\author{
Rosmaeni $^{1)}$, Nur Khalisah Latuconsina ${ }^{2)}$, and Nur Yuliany ${ }^{3)}$ \\ 1,2,3Fakultas Tarbiyah dan Keguruan UIN Alauddin Makassar

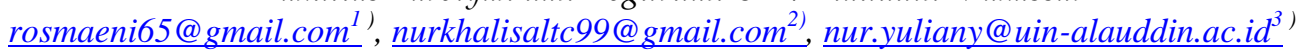

\begin{abstract}
Abstrak
Penelitian ini bertujuan untuk mengetahui perbedaan hasil belajar matematika peserta didik yang diajar dengan menggunakan model pembelajaran kooperatif tipe tutor sebaya dan tipe jigsaw pada kelas XI SMA Negeri 5 Jeneponto. Jenis penelitian ini adalah quasi experiment dengan desain penelitian non-equivalent control group design. Populasi penelitian ini adalah seluruh peserta didik kelas XI SMA Negeri 5 Jeneponto yang berjumlah 158 peserta didik terdiri atas kelas $\mathrm{XI}_{1}$ sampai dengan kelas $\mathrm{XI}_{4}$. Sampel dalam penelitian ini adalah kelas $\mathrm{XI}_{1}$ sebagai kelas eksperimen $n_{1}$ sedangkan $\mathrm{XI}_{2}$ sebagai kelas eksperimen ${ }_{2}$. Instrumen yang digunakan dalam penelitian ini adalah tes hasil belajar matematika berupa pretest dan posttest. Teknik analisis data yang digunakan adalah analisis statistik deskriptif dan analisis statistik inferensial. Hasil penelitian ini menunjukkan bahwa terdapat perbedaan rata-rata hasil belajar peserta didik yang diajar dengan menggunakan model pembelajaran kooperatif tipe tutor sebaya dengan tipe jigsaw dan model pembelajaran kooperatif tipe jigsaw lebih efektif dalam meningkatan hasil belajar matematika peserta didik pada kelas XI SMA Negeri 5 Jeneponto dibandingkan model pembelajaran kooperatif tipe tutor sebaya.
\end{abstract}

Kata Kunci: Pembelajaran Tutor Sebaya, Pembelajaran Jigsaw, Hasil Belajar Matematika

\section{Pendahuluan}

Pendidikan merupakan kebutuhan bagi kehidupan umat manusia yang harus dipenuhi sepanjang hayat. Tanpa pendidikan, mustahil manusia dapat mencapai aspirasi, cita-cita menuju masa depan. Pendidikan merupakan usaha sadar dan terencana untuk mewujudkan suasana belajar dan proses pembelajaran agar peserta didik secara aktif mengembangkan potensi dirinya untuk memiliki kekuatan spiritual, keagamaan, pengendalian diri, kepribadian, kecerdasan, akhlak mulia serta keterampilan yang diperlukan dirinya, masyarakat, bangsa dan Negara (Fuad, 2003). Upaya peningkatan mutu pendidikan haruslah dilakukan dengan menggerakkan seluruh komponen yang menjadi subsistem dalam suatu sistem mutu pendidikan. Salah satunya adalah guru dimana guru dalam proses pembelajaran harus mampu memahami karakteristik peserta didik sehingga tujuan pembelajaran dapat tercapai.

Salah satu materi pelajaran di sekolah adalah matematika. Nursalam (2013) mengemukakan bahwa pembelajaran matematika dikatakan efektif apabila peserta didik memahami konsep dari matematika dan mengaplikasikannya dalam kehidupan sehari-hari. Proses belajar mengajar matematika yang baik adalah guru harus mampu menerapkan suasana yang dapat membuat murid antusias terhadap persoalan yang ada sehingga mereka mampu mencoba memecahkan persoalannya. Proses pembelajaran membutuhkan metode yang tepat. Kesalahan menggunakan metode, dapat menghambat tercapainya tujuan pendidikan yang diinginkan. Dampak yang lain adalah rendahnya kemampuan bernalar peserta didik dalam pembelajaran matematika. Hal ini disebabkan karena dalam proses belajar mengajar peserta didik kurang dilibatkan dalam situasi optimal untuk belajar. Keberhasilan proses pembelajaran matematika dapat diukur dari tercapainya tujuan pembelajaran matematika. Keberhasilan itu dapat dilihat dari aktivitas guru yang mampu melaksanakan tugasnya dengan baik sebagai mediator, motivator dan fasilitator peserta didik sehingga peserta didik menjadi aktif dan kreatif serta pembelajaran pun menjadi efektif dan menyenangkan.

Mengingat begitu pentingnya proses belajar dalam pembelajaran yang dialami peserta didik maka seorang guru harus kompeten akan lebih mampu untuk membelajarkan peserta didik karena 
"mengetahui" tidak sepenting "memperoleh pengetahuan sendiri atau learning to learn". Peran guru dalam proses belajar mengajar bukan lagi menyampaikan pengetahuan melainkan memupuk pengetahuan serta membimbing peserta didik untuk belajar sendiri, karena keberhasilan peserta didik sebagian besar bergantung pada kemampuannya untuk belajarsecara mandiri dan memonitor belajar mereka sendiri (Felder, 1998).

Kenyataan yang terjadi di lapangan dapat dilihat bahwa hasil belajar peserta didik pada mata pelajaran matematika masih sangat rendah. Salah satu masalah pokok dalam pembelajaran matematika adalah masih rendahnya daya serap peserta didik. Berdasarkan hasil observasi di SMA Negeri 5 Jeneponto menyatakan bahwa pembelajaran yang selama ini dilakukan masih bersifat konvensional. Peserta didik pasif menerima pelajaran matematika hanya dengan mendengarkan penjelasan dari guru tanpa adanya keikutsertaan peserta didik dalam membangun pemahaman sendiri. Peserta didik juga hanya aktif mencatat materi sesuai dengan yang ditugaskan atau yang dituliskan oleh guru di papan tulis, sehingga hanya peserta didik yang memiliki tingkat pemahaman tinggi yang mampu menerima pelajaran dengan baik, sementara peserta didik yang lain hanya mengikuti arahan guru. Hal ini menyebabkan rendahnya hasil belajar matematika peserta didik. Oleh karena itu, guru matematika perlu memilih strategi yang tepat agar dapat menunjang kegiatan belajar mengajar, sehingga dapat dijadikan sebagai alat yang efektif untuk mencapai tujuan pembelajaran. Salah satu alternatif solusi dari permasalahan tersebut dapat menggunakan model pembelajaran kooperatif tipe tutor sebaya dan jigsaw.

Menurut Suherman dkk mengemukakan bahwa tutor sebaya adalah siswa yang pandai memberikan bantuan belajar kepada siswa yang kurang pandai. Sedangkan menurut Suryo dan Amin yang dimaksud dengan tutor sebaya adalah seorang atau berapa orang siswa yang ditunjuk dan ditugaskan untuk membantu siswa-siswa tertentu yang mengalami kesulitan belajar (Didi Suprijadi, 2010). Sedangkan model pembelajaran kooperatif tipe jigsaw menitikberatkan kepada kerja kelompok dalam bentuk kelompok kecil. Model jigsaw merupakan model belajar kooperatif dengan cara siswa belajar dalam kelompok kecil yang terdiri atas empat sampai dengan enam orang secara heterogen. Siswa bekerjasama saling ketergantungan positif dan bertanggung jawab secara mandiri (Aris Shoimin, 2016). Strategi pembelajaran tutor sebaya dapat meningkatkan hasil belajar peserta didik. (Santosa, 2008).

Hasil belajar adalah kemampuan yang diperoleh anak setelah melalui kegiatan belajar. Hasil belajar merupakan pencapaian bentuk perubahan perilaku yang cenderung menetap baik dilihat dari unsur segi kognitif, afektif dan psikomotorik dari proses belajar yang dilakukan dalam waktu tertentu, yang dihasilkan dari usaha yang dilakukan dengan cara latihan dan pengalaman belajar. Untuk memperoleh hasil belajar, diperlukan penialaian atau dilakukan evaluasi pada siswa yang merupakan tindak lanjut atau cara yang dilakukan untuk mengukur tingkat penguasaan siswa dalam proses pembelajaran yang telah dilakukannya, sehingga dengan evaluasi pendidik juga dapat mengukur tentang perubahan tingkah laku siswa secara nyata setelah dilakukan proses belajar mengajar yang sesuai dengan tujuan pengajaran (Asep Jihad, 2012). Berdasarkan beberapa penjelasan tersebut penulis terdorong untuk mengkaji lebih jauh penelitian tentang efektivitas model pembelajaran kooperatif tipe tutor sebaya dan tipe jigsaw terhadap hasil belajar matematika siswa.

\section{Metode Penelitian}

Jenis penelitian ini adalah quasi experimental dengan desain penelitian non equivalent control group design. Dalam desain ini terdapat dua kelompok eksperimen yang diberi perlakuan yang sama 
berupa pretest dan posttest. Tes pretest diberikan sebelum adanya perlakuan untuk mengetahui keadaan awal peserta didik, sedangkan posttest diberikan setelah adanya perlakuan untuk mengetahui peningkatan hasil belajar peserta didik. Penelitian ini dilaksanakan SMA Negeri 5 Jeneponto, Kecamatan Batang, Kabupaten Jeneponto.

Populasi pada penelitian ini adalah seluruh peserta didik kelas XI SMAN 5 Jeneponto tahun ajaran 2017-2018. Adapun teknik pengambilan sampel dalam penelitian ini adalah purposive sampling sehingga sampelnya terdiri dari dua kelas yaitu kelas $\mathrm{XI}_{1}$ sebagai kelas eksperimen $n_{1}$ yang diterapkan model pembelajaran kooperatif tipe tutor sebaya dengan jumlah siswa sebanyak 40 orang dan kelas $\mathrm{XI}_{2}$ sebagai kelas eksperimen $n_{2}$ yang diterapkan model pembelajaran kooperatif tipe jigsaw dengan jumlah siswa sebanyak 40 orang, jadi sampel dalam penelitian sebanyak 80 orang. Instrumen tes yang digunakan berbentuk tes uraian untuk mengukur hasil belajar matematika siswa dengan jumlah soal sebanyak enam nomor. Pengolahan data hasil penelitian yang digunakan adalah statistik deskriptif dan statistik inferensial yaitu uji independent sample t-test dan uji efisiensi relative.

\section{Hasil}

Penelitian ini diawali dengan memberikan pretest untuk mengukur hasil belajar awal peserta didik. Adapun hasil belajar matematika peserta didik secara deskriptif dapat dilihat pada tabel berikut:

Tabel 1. Data Pretest Hasil Belajar Matematika Kelas Eksperimen

\begin{tabular}{lccccc}
\hline & N & Max & Min & Mean & Standar Deviasi \\
\hline Kelas Eksperimen $_{1}$ & 40 & 59 & 30 & 45,4 & 8,97 \\
Kelas Eksperimen $_{2}$ & 40 & 68 & 33 & 44,4 & 6,65 \\
\hline
\end{tabular}

Berdasarkan tabel di atas, dapat diketahui bahwa nilai tertinggi pretest pada kelas eksperimen ${ }_{1}$ yaitu 59 dan pada kelas eksperimen ${ }_{2}$ yaitu 68 . Sedangkan nilai terendah pada kelas eksperimen n $_{1}$ yaitu 30 dan kelas eksperimen ${ }_{2}$ yaitu 33. Rata-rata hasil belajar matematika pada kelas eksperimen ${ }_{1}$ yaitu 45,4 dan kelas eksperimen 2 yaitu 44,4. Hal ini menunjukkan bahwa rata-rata kemampuan awal peserta didik baik pada kelas eksperimen ${ }_{1}$ maupun kelas eksperimen $_{2}$ tidak mencapai kriteria ketuntasan yaitu di atas nilai $K K M \geq 70$.

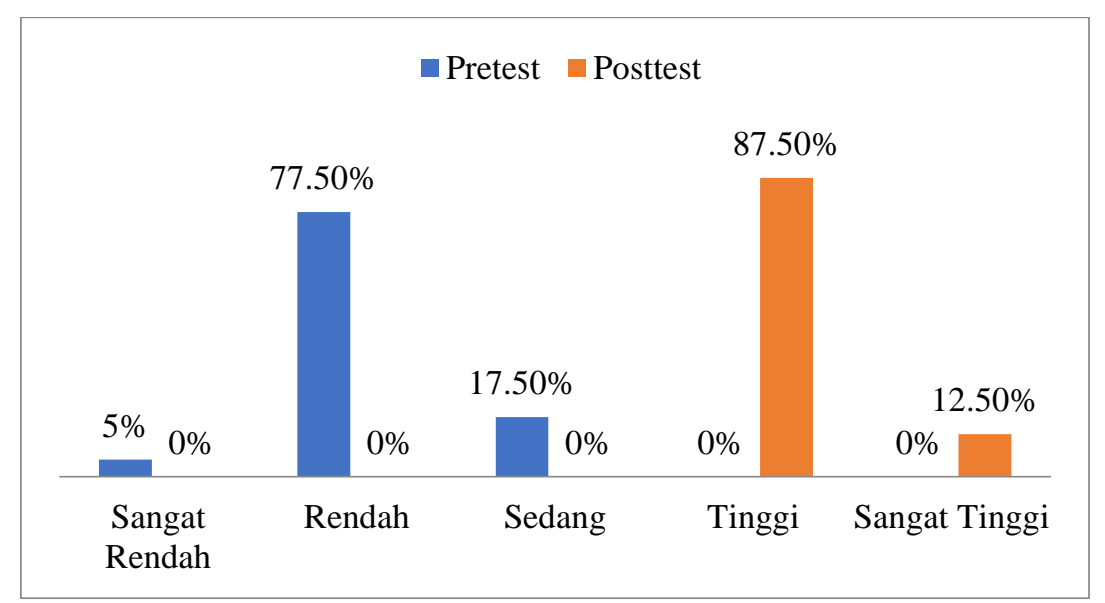

Gambar 1. Hasil Pretest Dan Posttest Pada Kelas Eksperimen 1

Berdasarkan diagram di atas menunjukkan bahwa pada pretest rata-rata peserta didik berada pada kategori sangat rendah yaitu $77,5 \%$ sedangkan pada posttest rata-rata peserta didik berada pada 
kategori tinggi yaitu $87,5 \%$. Hal ini terjadi karena dalam proses pembelajaran yang diterapkan dengan model pembelajaran kooperatif tipe tutor lebih menekankan pada metode kerja sama sehingga terjadi interaksi dalam kelompok. Pembagian kelompok dalam metode ini berdasarkan jumlah tujuan pembelajaran yang ingin dicapai sehingga tutor akan disebar ke tiap-tiap kelompok untuk mengajarkan materi yang diberikan kepada anggota kelompoknya.

Tutor yang dipilih harus memiliki kemampuan yang lebih dibandingkan anggotanya. Dengan metode ini juga peserta didik akan merasa terbantu dengan adanya tutor yang menjelaskan dalam kelompok. Peserta didik juga akan memiliki kebebasan untuk bertanya secara langsung kepada tutor karena yang menjadi tutor adalah temannya sendiri sehingga peserta didik akan memiliki peluang untuk menguasai materi pembelajaran. Dari peningkatan hasil belajar peserta didik tersebut dapat disimpulkan bahwa model pembelajaran kooperatif tipe tutor sebaya efektif dalam meningkatkan hasil belajar matematika peserta didik pada materi matriks.

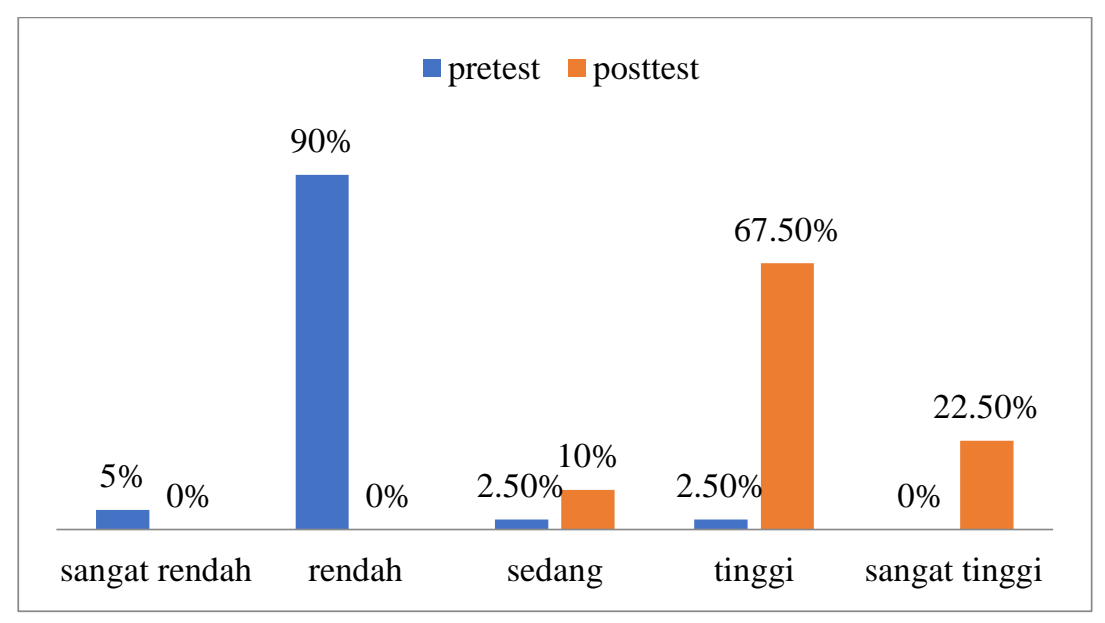

Gambar 2. Hasil Pretest dan Posttest Kelas Eksperimen 2

Berdasarkan diagram di atas menunjukkan bahwa pada pretest rata-rata peserta didik berada pada kategori sangat rendah yaitu $90 \%$ sedangkan pada posttest rata-rata peserta didik berada pada kategori tinggi yaitu $67,5 \%$. Hal ini terjadi karena dalam proses pembelajaran yang diterapkan dengan model pembelajaran kooperatif tipe jigsaw lebih menekankan pada metode kerja sama sehingga terjadi interaksi dalam kelompok dimana jumlah anggota dalam tiap kelompok berdasarkan jumlah tujuan pembelajaran yang ingin dicapai.

Melalui metode ini peserta didik akan belajar untuk bertanggung jawab secara mandiri karena dalam kelompoknya masing-masing memiliki materi yang berbeda-beda. Dalam pelaksanaan metode ini terdapat dua kelompok yaitu kelompok asal dan kelompok ahli. Kelompok ahli yaitu kelompok peserta didik yang memiliki materi yang sama dan saling mendiskusikan materinya satu sama lain sedangkan kelompok asal adalah kelompok awal peserta didik di mana dalam kelompok ini peserta didik akan bergantian menjadi tutor untuk menjelaskan materinya secara mandiri berdasarkan hasil diskusi dari kelompok ahli.

Kegiatan presentasi, peserta didik yang ditunjuk untuk melakukan presentasi harus menjelaskan materi secara keseluruhan. Dari kegiatan ini peserta didik memiliki peluang untuk menguasai tujuan pembelajaran yang ingin dicapai. Dari peningkatan hasil belajar peserta didik 
tersebut dapat disimpulkan bahwa model pembelajaran kooperatif tipe jigsaw efektif dalam meningkatkan hasil belajar matematika peserta didik pada materi matriks.

Tabel 2. Normalitas Hasil Belajar Pretest Kelas Eksperimen

\begin{tabular}{cccc}
\hline Kelas & K- Smirnov $\boldsymbol{Z}$ & Sig & Keterangan \\
\hline Eksperimen $_{1}$ & .652 & .789 & Normal \\
Eksperimen $_{2}$ & .699 & .713 & Normal \\
\hline
\end{tabular}

Pengujian normalitas dilakukan pada data pretest kelas eksperimen ${ }_{1}$ dan kelas eksperimen ${ }_{2}$,

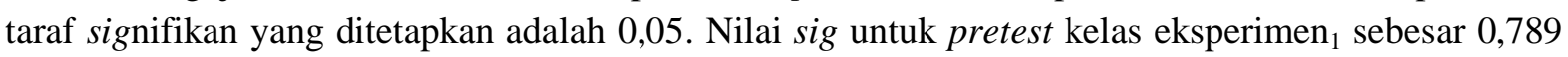
berarti nilai sig $>\alpha(0,789>0,05)$, jadi dapat disimpulkan bahwa data pretest kelas eksperimen ${ }_{1}$

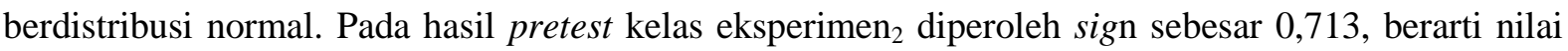
sig >nilai $\alpha(0,713>0,05)$, jadi dapat disimpulkan bahwa data pretest kelas eksperimen ${ }_{2}$ juga berdistribusi normal.

Tabel 3. Normalitas Hasil Belajar Posstest Kelas Eksperimen

\begin{tabular}{cclc}
\hline Kelas & K-Smirnov $\boldsymbol{Z}$ & Sig & Keterangan \\
\hline Eksperimen $_{1}$ & 1.003 & .266 & Normal \\
Eksperimen $_{2}$ & .897 & .397 & Normal \\
\hline
\end{tabular}

Pengujian normalitas dilakukan pada data posttest kelas eksperimen ${ }_{1}$ dan kelas eksperimen ${ }_{2}$, taraf signifikan yang ditetapkan adalah 0,05, setelah dilakukan pengolahan data pada SPSS maka

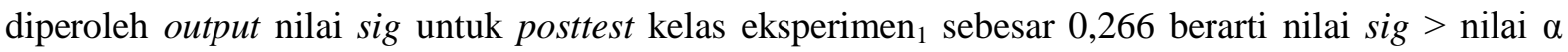

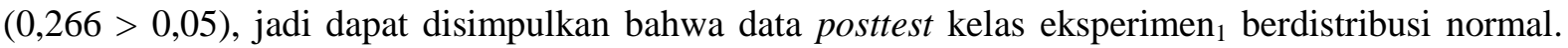
Pada hasil posttest kelas eksperimen ${ }_{2}$ diperoleh sig sebesar 0,397, berarti nilai sig $>\alpha(0,397>0,05)$,

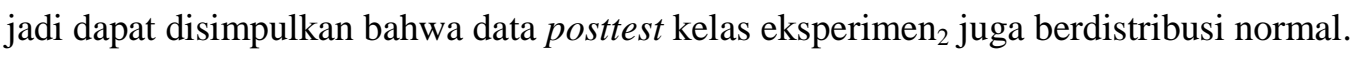

Tabel 4. Homogenitas Hasil Belajar Pretest Kelas Eksperimen

\begin{tabular}{cccc}
\hline Tes & Levene Statistik & Sig & Keterangan \\
\hline Pretest & 1.867 & .176 & Homogen \\
Posttest & 3.628 & .060 & Homogen \\
\hline
\end{tabular}

Berdasarkan tabel di atas dapat diketahui bahwa pada kelas eksperimen ${ }_{1}$, besarnya angka Levene Statistik adalah 1.867 sedangkan probabilitas atau signifikansinya adalah 0,176 yang berarti lebih besar dari 0,05 dengan demikian $\mathrm{H}_{0}$ diterima, yang berarti asumsi bahwa data pretest kedua kelas eksperimen variansinya sama (homogen). Sedangkan untuk posttest kelas eksperimen dan kelas eksperimen $_{2}$ diketahui bahwa besarnya angka Levene Statistik adalah 3.628 sedangkan probabilitas atau signifikansinya adalah 0,060 yang berarti lebih besar dari 0,05 dengan demikian $\mathrm{H}_{0}$ diterima, yang berarti asumsi bahwa data posttest kedua kelas eksperimen variansinya sama (homogen).

Tabel 5. Uji Hipotesis Kelas Eksperimen

\begin{tabular}{|c|c|c|c|c|c|c|c|}
\hline Kelas & $\mathbf{F}$ & $t_{-h i t}$ & $t_{- \text {tabel }}$ & Df & Mean & Sig. & Keterangan \\
\hline Posttest & 3.628 & .454 & .219 & 8 & 1.487 & .651 & $\mathrm{H}_{1}: \mu_{1} \neq \mu_{2}$ \\
\hline
\end{tabular}


Berdasarkan tabel di atas, maka diketahui nilai sig sebesar 0,651, $\alpha=0,05 \mathrm{dan} \mathrm{dk}=(40+40-$ $2)=78$ adalah 0,2199 . Karena $t_{\text {hitung }}>t_{\text {tabel }}(0,651>0,2199)$ maka dapat disimpulkan bahwa $\mathrm{H}_{0}$ ditolak dan $\mathrm{H}_{1}$ tak di tolak. Jadi dapat disimpulkan bahwa terdapat perbedaan rata-rata dalam penerapan model pembelajaran kooperatif tipe tutor sebaya dengan tipe jigsaw terhadap hasil belajar matematika siswa kelas XI SMA Negeri 5 Jeneponto.

Tabel 6. Uji Efektivitas Kelas Eksperimen

\begin{tabular}{cccc}
\hline Kelas & Variansi Eksperimen $_{\mathbf{1}}$ & Variansi Eksperimen $_{\mathbf{2}}$ & $\mathbf{R}_{\left(\boldsymbol{\theta}_{\mathbf{2}}, \boldsymbol{\theta}_{\mathbf{1}}\right)}$ \\
\hline Posttest & 72.25 & 55.80 & 1.29 \\
\hline
\end{tabular}

Berdasarkan uraian di atas maka $R>1$, sehingga dapat disimpulkan bahwa $\theta_{2}$ lebih efisien dibandingkan $\theta_{1}$ atau model pembelajaran kooperatif tipe jigsaw lebih efektif dalam meningkatkan hasil belajar matematika peserta didik kelas XI SMA Negeri 5 Jeneponto dibandingkan model pembelajaran kooperatif tipe tutor sebaya. Hal ini terjadi karena adanya perbedaan dalam langkahlangkah pembelajaran terutama pada kagiatan diskusi dan presentasi. Di mana dalam kegiatan diskusi peserta didik masing-masing memiliki materi secara mandiri meskipun bekerja dalam kelompok. Peserta didik akan bergantian menjadi tutor untuk menjelaskan materi dalam kelompoknya sehingga peserta didik harus menguasai tujuan pembelajaran yang ingin dicapai dan dalam kegiatan presentasi, peserta didik yang ditunjuk ntuk melakukan presentasi harus menjelaskan materi secara keseluruhan. Dengan kegiatan ini peserta didik antusias dalam menguasai materi pembelajaran. Sedangkan pada pembelajaran kooperatif tipe tutor sebaya dalam kegiatan diskusi setiap kelompok hanya mendapatkan satu sub pokok materi dan pada saat presentasi, semua kelompok melakukan presentasi karena setiap kelompok memiliki materi yang berbeda-beda sehingga setelah peserta didik melakukan presentasi, maka akan cenderung memperhatikan kelompok lain untuk melakukan presentasi.

Meskipun terjadi perbedaan dalam proses pembelajaran, namun kedua model pembelajaran yang diterapkan efektif dalam meningkatkan hasil belajar matematika peserta didik pada materi matriks karena dalam proses penerapannya, peserta didik saling bekerja sama secara berkelompok sehingga terjadi interaksi baik antar peserta didik maupun dengan pendidik. Strategi ini berlandaskan pada teori belajar Vygotsky yang menekankan pada interaksi sosial sebagai sebuah mekanisme untuk mendukung perkembangan kognitif (Muh. Yusuf T, 2013).

\section{Pembahasan}

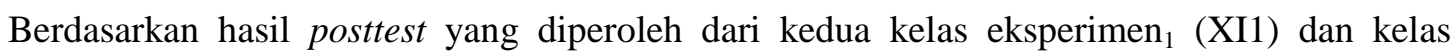
eksperimen $_{2}$ (XI2) pada materi matriks, terdapat perbedaan hasil belajar antara kelas yang diterapkan model pembelajaran kooperatif tipe tutor sebaya (XI1) dan kelas yang diterapkan model pembelajaran kooperatif tipe jigsaw (XI2). Hal ini di buktikan dengan hasil pengujian statistik inferensial pada uji t diperoleh $\mathrm{t}_{\text {hitung }}>\mathrm{t}_{\text {tabel }}$ dimana, $\mathrm{t}_{\text {hitung }}=0,651$ sedangkan tabel $=0,2199$ menunjukkan $\mathrm{H}_{0}$ ditolak dan $\mathrm{H}_{1}$ tak ditolak, sehingga dapat disimpulkan bahwa terdapat perbedaan rata-rata dalam penerapan model pembelajaran kooperatif tipe tutor sebaya dengan tipe jigsaw terhadap hasil belajar matematika siswa kelas XI SMA Negeri 5 Jeneponto.

Setelah dilakukan pengolahan data, meskipun terdapat perbedaan pada kedua model tersebut, namun tetap dinyatakan bahwa kedua model tersebut efektif digunakan dalam meningkatkan hasil belajar matematika peserta didik. Namun untuk membandingkan efektivitas antara model pembelajaran kooperatif tipe tutor sebaya dan tipe jigsaw, maka digunakan uji efektivitas hasil belajar 
peserta didik. Berdasarkan hasil uji efektivitas maka dipeoleh hasil bahwa $\mathrm{R}>1$, sehingga dapat disimpulkan bahwa model pembelajaran kooperatif tipe jigsaw lebih efektif dalam meningkatkan hasil belajar matematika peserta didik kelas XI SMA Negeri 5 Jeneponto dibandingkan model pembelajaran kooperatif tipe tutor sebaya. Hal ini terjadi karena adanya perbedaan dalam langkahlangkah model pembelajaran yang dilakukan pada saat proses pembelajaran terutama pada saat diskusi dan presentasi hasil diskusi. Dimana, pada model pembelajaran kooperatif tipe jigsaw pada sesi diskusi, peserta didik masing-masing memiliki materi sendiri dalam kelompoknya dan materi tersebut harus dikuasai setiap individu karena nantinya akan membentuk kelompok baru yaitu kelompok ahli. Dalam kelompok inilah peserta didik berkumpul berdasarkan materi yang sama kemudian saling berdiskusi dan bertukar fikiran antara peserta didik yang satu dengan peserta didik yang lainnya mengenai materi yang diberikan sehingga wawasan peserta didik tidak terbatas hanya pada pengetahuannya saja namun pengetahuan peserta didik dapat bertambah luas dengan adanya saran atau pengetahuan yang diperoleh dari orang lain dan setelah berdiskusi setiap individu kembali ke kelompok asal untuk menjelaskan hasil diskusi dari kelompok ahli tersebut. Dalam diskusi ini peserta didik menjelaskan materi yang diberikan secara bergantian dalam kelompoknya sehingga memungkinkan peserta lebih menguasai sub-sub materi yang dibahas pada pertemuan tersebut karena ada beberapa materi yang dibahas dalam setiap kelompok dan materi tersebut harus dikuasi oleh setiap individu. Setelah semua kelompok berdiskusi guru bertugas untuk menunjuk salah satu individu untuk menjelaskan hasil diskusi dalam kelompoknya. Individu yang bertugas untuk mempresentasikan hasil diskusi harus menjelaskan materi secara keseluruhan sehingga peserta didik akan lebih antusias dalam meguasai materi pelajaran. Kelompok lain diberikan kesempatan untuk menanggapi penjelasan dari presentasi hasil diskusi agar peserta didik saling bertukar informasi satu sama lain.

Berdasarkan hasil diskusi tersebut, peserta didik memiliki peluang yang besar untuk memahami materi secara keseluruhan. Sedangkan pada model pembelajaran kooperatif tipe tutor sebaya, peserta didik hanya mendapatkan satu tujuan pembelajaran dalam kelompoknya masingmasing sehingga pengetahuan peserta didik terhadap materi yang lain sangat minimalisir karena hanya terfokus pada satu materi saja apalagi jika peserta didik tidak memperhatikan kelompok lain yang melakukan presentasi hasil diskusi, maka pengetahuan peserta didik hanya terbatas pada materi yang dibagikan secara kelompok. Meskipun terjadi perbedaan dalam proses pembelajaran, namun kedua model pembelajaran yang diterapkan efektif dalam meningkatkan hasil belajar matematika peserta didik pada materi matriks karena dalam proses penerapannya, peserta didik saling bekerja sama secara berkelompok sehingga terjadi interaksi baik antar peserta didik maupun dengan pendidik. Strategi ini berlandaskan pada teori belajar Vygotsky yang menekankan pada interaksi sosial sebagai sebuah mekanisme untuk mendukung perkembangan kognitif. Hasil penelitian ini sejalan dengan Santosa (2017) yang mengatakan bahwa pada siklus I, hasil belajar dari 40 siswa terdapat 20 siswa (50\%) dikategorikan tidak tuntas belajar yaitu mendapat nilai kurang dari 65, sedangkan siswa yang tuntas belajar klasikal ada 20 siswa (50\%) dikategorikan tuntas belajar klasikal dengan daya serap $50 \%$ terhadap materi pelajaran, kemudian pada siklus II, hasil belajar siswa juga terjadi peningkatan dalam menyelesaikan soal, terbukti dari siswa yang tidak tuntas belajar dari 20 siswa menjadi 10 siswa, sedangkan siswa yang tuntas belajar klasikal ada 30 siswa dengan daya serap $64 \%$ dan pada siklus III, hasil belajar siswa mengalami peningkatan kemampuan terhadap penyelesaian soal, terbukti dari siswa yang tuntas belajar klasikal tinggal 4 siswa (10\%) yang tidak tuntas sedangkan siswa yang tuntas belajar klasikal ada 36 siswa (90\%) dengan daya serap 68\%, berarti ada peningkatan kemampuan siswa dalam menyelesaikan soal keliling dan luas segitiga. 


\section{Kesimpulan}

Berdasarkan hasil penelitian dan pembahasan dalam penelitian ini, dapat disimpulkan bahwa: (1) Hasil belajar matematika peserta didik kelas $\mathrm{XI}_{1}$ SMA Negeri 5 Jeneponto yang diajar dengan menggunakan model pembelajaran kooperatif tipe tutor sebaya mengalami peningkatan dari 45,4 menjadi 79,2 setelah diberikan posttest dengan peningkatan sebesar 74,4\%. (2) Hasil belajar matematika peserta didik kelas $\mathrm{XI}_{2} \mathrm{SMA}$ Negeri 5 Jeneponto yang diajar dengan menggunakan model pembelajaran kooperatif tipe jigsaw mengalami peningkatan dari 44,4 menjadi 78,8 setelah diberikan posttest dengan peningkatan sebesar 77,5\%. (3) Terdapat perbedaan hasil belajar matematika peserta didik yang diajar menggunakan model pembelajran kooperatif tipe tutor sebaya dan tipe jigsaw. Dimana model pembelajaran kooperatif tipe jigsaw lebih efektif dalam meningkatkan hasil belajar matematika peserta didik dibandingkan model pembelajaran kooperatif tipe tutor sebaya.

\section{Daftar Pustaka}

Arikunto, S. (2006). Prosedur Penelitian Suatu Pendekatan Praktik. Jakarta: Rineka Cipta.

Felder, R.M, Learning and teaching styles in engineering Of Education (Eng Education: 1998): h. 674-681.

Fuad, I. (2003). Dasar-Dasar Kependidikan. Jakarta: Rineka Cipta.

Hasan, I. (2002). Pokok-Pokok Materi Statistik. Jakarta: BumiAksara.

Nursalam. (2013). Strategi Pembelajaran Matematika. Makassar: Alauddin University Pess.

Jihad, A. (2012). Evaluasi Pembelajaran. Yogyakarta: Multi Pressindo.

Setiawan Santosa, Penerapan Model Pembelajaran Cooperative Learning Tipe Jigsaw Untuk Meningkatkan Hasil Belajar Peserta Didik Kelas VII B Smp N 8 Pekalongan Pada Materi Pokok Segitiga, (Semarang: Fakultas Matematika dan Ilmu Pendidikan UniversitasNegeri Semarang, 2008), h. 39-40.

Shoimin, A. (2016). 68 Model Pembelajaran Inovatif Dalam Kurikulum 2013. Jakarta: Ar-ruzz Media.

Suprijadi, D. (2010). Pengaruh Tutor Sebaya Terhadap Hasil Belajar Matematika Siswa Kelas VII SMP Daarussalaam Jakarta, Vol. 3,No. 2. Jakarta: Fakultas Teknik, Matematika dan Ilmu Pengetahuan Alam Universitas Indraprasta PGRI.

Yusuf, M.T. (2013). Teori Belajar Dalam Praktek. Makassar: Alauddin University Press. 